\title{
PENERAPAN SISTEM PENILAIAN PRESTASI KERJA PEGAWAI NEGERI SIPIL DI KANTOR REGIONAL III BADAN KEPEGAWAIAN NEGARA
}

\author{
Bina Danny R. Gani \\ Pascasarjana UIN Sunan Gunung Djati Bandung \\ E-mail: binadannyo7@gmail.com
}

\begin{abstract}
Work performance assessment is required and must be arranged by every civil servant, consists four aspects of employee work target which are quantity, quality, working-time and cost. In its application, there are subjectivity in time and cost aspects evaluation, which will affect the civil servant. This paper describes the work performance assessment at the Regional Office III of State Human Resources Institution including their efforts to overcome problems that raised in the assessment process. The results shows that the work performance assessment was executed in objective manners in each aspect excluding working-time and costs aspects, since the applied working-time is different for each civil servant type of job. Whilst in the costs aspect, minimal score was given due to low target achievement. For this reason, there is a demand to improve related regulation in formulating the time and costs aspects evaluation, in order to make a more objective assessment for all civil servant in every level.
\end{abstract}

Keyword : work performance assessment, employee work target, employee behaviour, civil servant promotion

\begin{abstract}
Abstrak
Penilaian prestasi kerja PNS wajib dibuat dan disusun oleh seluruh PNS, dengan penilaian sasaran kerja pegawai (SKP) dari empat aspek yaitu aspek kuantitas, aspek kualitas, aspek waktu, dan aspek biaya. Dalam implementasinya ditemukan ketidakobjektifan yang akan berpengaruh terhadap kenaikan pangkat PNS. Tujuan tulisan ini adalah untuk menggambarkan penilaian prestasi kerja di Kantor Regional III Badan Kepegawaian Negara serta kendala dan langkah-langkah yang dapat diambil dalam mengatasi kendala yang ditemui. Pada kantor regional tersebut ditemukan bahwa penilaian prestasi kerja PNS sudah objektif untuk aspek aspek kuantitas, aspek kualitas, dan aspek perilaku kerja; dan belum objektif untuk aspek waktu dan aspek biaya. Kendala dalam aspek waktu meliputi satuan waktu yang digunakan dan karakteristik dari uraian tugas yang berbeda untuk setiap jabatan PNS.
\end{abstract}

Keyword: penilaian prestasi kerja, sasaran kerja pegawai, perilaku kerja, kenaikan pangkat PNS 


\section{Pendahuluan}

"Pegawai merupakan tenaga kerja manusia jasmaniah maupun rohaniah yang senantiasa dibutuhkan dan oleh karena itu menjadi salah satu modal pokok dalam mencapai tujuan organisasi". ${ }^{1}$ "Mereka dipekerjakan dalam suatu badan tertentu, baik di lembaga-lembaga pemerintah maupun dalam badan-badan usaha". ${ }^{2}$ Pendapat lain menyatakan bahwa "pegawai adalah mereka yang secara langsung digerakkan oleh manajer sebagai pelaksana pekerjaan untuk menghasilkan karya-karya yang dapat mewujudkan tujuan organisasi" ${ }^{3}$

Berdasarkan definisi tersebut dapat diketahui bahwa pegawai adalah salah satu modal pokok dalam suatu organisasi, baik di pemerintahan maupun swasta. Sebagai unsur manusia dalam suatu organisasi maka keberadaan serta kemampuan dan keterampilan pegawai akan menentukan tercapai tidaknya tujuan suatu organisasi. Salah satu bentuk organisasi adalah negara.

Negara merupakan sebuah organisasi dalam suatu wilayah kekuasaan yang dapat memaksakan kewenangannya secara sah terhadap semua golongan kekuasaan lainnya serta dapat menetapkan tujuan yang hendak dicapai dari kehidupan bersama ${ }^{4}$. Pengertian lain dikemukakan oleh Logeman bahwa "negara adalah organisasi berbasis masyarakat yang memiliki kekuasaan untuk mengontrol dan mengurusi masyarakat tertentu". 5

Berdasarkan uraian di atas dapat ditarik kesimpulan bahwa negara Indonesia merupakan sebuah organisasi dimana individu merupakan bagian yang tidak terpisahkan dari negara yang memiliki fungsi dan kedudukan untuk menjalankan negara. Dalam konteks ini individu yang dimaksud adalah seseorang yang bekerja pada Pemerintah atau Negara. Dalam kehidupan sehari-hari mereka yang bermajikan Negara ini biasanya disebut dengan pegawai negeri. Di dalam Undang-Undang Aparatur Sipil Negara No. 5 Tahun 2014 tentang Aparatur Sipil Negara pasal 1 ayat 3 dinyatakan sebagai berikut :

"Pegawai Negeri Sipil yang selanjutnya disingkat PNS adalah warga negara Indonesia yang memenuhi syarat tertentu, diangkat sebagai Pegawai ASN secara tetap oleh pejabat pembina kepegawaian untuk menduduki jabatan pemerintahan".

PNS merupakan unsur abdi negara, abdi masyarakat, dan aparatur negara yang wajib setia dan taat kepada Pancasila sebagai ideologi bangsa, Undang-Undang Dasar 1945 dan Pemerintah. PNS mempunyai kedudukan sebagai unsur aparatur negara dengan tugas pokok utama sebagai pelayan publik. Hal ini sesuai dengan amanat PP No

\footnotetext{
${ }^{1}$ A.W.Widjaja, Administraasi Kepegawaian (Jakarta: Rajawali Pres, 2007), hlm.113.

${ }^{2}$ Ibid, hal.4.

${ }^{3}$ Musanef, Manajemen Kepegawaian di Indonesia (Jakarta: Gunung Agung, 2005), hlm 5.

${ }^{4}$ Miriam Budiarjo, Dasar-Dasar Ilmu Politik (Jakarta: PT.Gramedia Pustaka Utama, 2008), hlm.13.

${ }^{5}$ K.Putrigiri Sekarningrum, Warga Negara dan Negara, diakses dari http://putrigirisekar.blogspot .co.id/2016/12/makalah-tentang-warga-negara-dan-negara/, pada tanggal 14 November 2017 pukul 22.28

${ }^{6}$ Undang - Undang No. 5 Tahun 2014 tentang Aparatur Sipil Negara, hlm. 3
} 
53 tahun 2010 tentang Disiplin PNS dimana salah satu kewajiban PNS yaitu memberikan pelayanan secara professional dan merata kepada masyarakat sesuai dengan tugas pokok dan fungsi masing-masing dalam mendukung penyelenggaraan tugas negara dan pembangunan.

Kedudukan PNS sebagai aparatur negara memiliki peranan penting sebagai ujung tombak dalam menentukan keberhasilan penyelenggaraan pembangunan dan pemerintahan. Arti penting ini dikarenakan fungsinya yang sentral, karena sangat menentukan dalam pembangunan bangsa dan negara, diantaranya sebagai unsur dalam menciptakan pemerintahan yang bersih dan pemerintahan yang baik, memiliki posisi strategis dan kontribusi besar dalam upaya melakukan reformasi birokrasi dimana PNS sebagai kader utama dalam birokrasi yang akan melanjutkan estafet kepemimpinan selanjutnya. "Selain itu juga PNS memiliki fungsi sebagai pelaksana kebijakan publik dan perekat pemersatu bangsa".

Dalam rangka mewujudkan tujuan nasional maka sangat dibutuhkan sosok PNS yang mampu melaksanakan peran di atas, yaitu PNS yang memiliki kualifikasi dan kompetensi dalam perilakunya yang setia dan taat kepada Pancasila, UUD 1945, professional, bermoral, jujur, adil, dan sadar akan tanggung jawabnya sebagai pelayan masyarakat.

Menurut UU No. 43 tahun 1999 tentang Pokok-Pokok Kepegawaian Jo. UU No. 5 tahun 2014 tentang Aparatur Sipil Negara pasal 12 dan pasal 20 disebutkan bahwa; "untuk menciptakan PNS yang professional, bertanggungjawab, jujur dan adil, diwujudkan melalui Penilaian Prestasi Kerja, yaitu melalui pembinaan yang dilaksanakan berdasarkan sistem prestasi kerja dan sistem karier yang dititikberatkan pada sistem prestasi kerja serta untuk menjamin obyektivitas dalam mempertimbangkan pengangkatan jabatan dan kenaikan pangkat".

Di era globalisasi yang penuh tantangan dan kompetisi, pemerintah terus berupaya meningkatkan kinerja PNS. Salah satu upaya tersebut adalah penerbitan Peraturan Pemerintah No. 46 Tahun 2011 tentang penilaian prestasi kerja PNS. Dengan terbitnya Peraturan Pemerintah tersebut diharapkan dapat memperbaiki kekurangan dan kelemahan dari peraturan yang sebelumnya, yaitu Peraturan Pemerintah Nomor 10 tahun 1979 tentang penilaian pelaksanaan pekerjaan PNS. Salah satu perbaikan tersebut yaitu dengan adanya pendekatan baru dalam mengukur kinerja PNS yaitu Sasaran Kinerja Pegawai (SKP) yang lebih terukur.

Penilaian kinerja PNS dengan SKP membawa harapan baru dalam peningkatan kinerja dan kualitas kerja PNS, sesuai dengan ketentuan dalam pasal 75 UU No. 5 Tahun 2014 tentang Aparatur Sipil Negara bahwa; "penilaian prestasi kerja PNS dilaksanakan dengan tujuan untuk menjamin objektivitas pembinaan PNS yang dilakukan berdasarkan sistem prestasi kerja dan sistem karir yang dititikberatkan pada sistem prestasi kerja".

\footnotetext{
${ }^{7}$ Ibid., hlm. 10
} 
"Dalam penilaian prestasi kerja PNS terdapat beberapa prinsip, yaitu prinsip objektif, akuntabel, terukur, transparan, dan partisipatif". ${ }^{8}$ Objektif atas apa yang dituangkan dalam SKP dan benar atas apa yang menjadi tugas jabatannya, terukur pada tugas jabatan yang dilaksanakan PNS dan harus kuantitatif atau pekerjaan tersebut dapat diukur prestasinya, akuntabel yaitu SKP yang dibuat harus bisa dipertanggungjawabkan serta partisipatif dimana telah terjadi komunikasi dua arah atas kontrak kerja antara PNS dengan atasannya dan SKP tersebut bersifat terbuka dari mulai tahap membuat target sampai dengan penilaiannya tidak bersifat rahasia.

"Penilaian prestasi kerja pegawai dilaksanakan setiap tahun dengan membandingkan antara capaian dengan target yang telah ditetapkan diawal tahun dan ditambahkan dengan tugas tambahan dan kreativitas jika ada. Penilaian akhir dari prestasi kerja tersebut dilakukan dengan cara menggabungkan penilaian SKP dengan penilaian perilaku kerja. Bobot nilai dari masing-masing unsur penilaian di atas adalah $60 \%$ untuk unsur SKP dan 40\% untuk unsur perilaku kerja". ${ }^{9}$

SKP memuat target kinerja yang akan dicapai oleh seorang PNS dalam satu tahun ke depan, yang isinya "meliputi 4 (empat) aspek yaitu aspek kuantitas, aspek kualitas, aspek waktu, dan aspek biaya". ${ }^{10}$ Adapun perilaku kerja seorang PNS dinilai apakah telah sesuai dengan ketentuan peraturan perundang-undangan yang berlaku yang meliputi aspek integritas, orientasi pelayanan, disiplin, komitmen, kepemimpinan, dan kerjasama.

Dalam implementasinya, SKP yang sifatnya wajib disusun oleh setiap pegawai negeri sipil ini masih belum ada persamaan persepsi dalam penyusunannya terutama dari aspek waktu yang harus digunakan, baik dalam penentuan target maupun realisasinya. Di Peraturan Pemerintah Nomor 46 tahun 2011 ataupun Peraturan Kepala BKN Nomor 1 tahun 2013 sebagai petunjuk teknis pelaksanaan penilaian prestai kerja PNS, tidak disebutkan secara spesifik untuk satuan-satuan waktu yang dapat digunakan untuk penyusunan aspek waktu dalam SKP. Saat ini satuan waktu yang harus digunakan adalah hitungan bulan. Hal ini mengakibatkan tugas pokok dan fungsi (tupoksi) masing-masing PNS dipaksakan baik target maupun realisasinya dalam jangka waktu sekian bulan sehingga penilaian SKP dari aspek waktu pun menjadi tidak objektif. Tentu saja hal ini sudah keluar dari prinsip objektif penilaian prestasi kerja karena SKP sudah tidak presisi lagi dengan kenyataan di lapangan dimana banyak pekerjaan PNS yang bisa ditargetkan dan selesai dikerjakan dalam hitungan minggu, hari, bahkan jam. Begitu pula dengan karakteristik dari kegiatan tugas jabatan atau tupoksi dari masing-masing pegawai yang berbeda untuk masing-masing jabatan, hal ini memberi peluang yang berbeda pula dalam perolehan nilai capaian SKP Pegawai Negeri Sipil.

\footnotetext{
${ }^{8}$ Peraturan Pemerintah No. 46 Tahun 2011 Tentang Penilaian Prestasi Kerja Pegawai Negeri Sipil, hlm. 3

${ }^{9}$ Ibid., hlm. 8

${ }^{10} \mathrm{Ibid}$., hlm. 5
} 
Aspek biaya pun perlu adanya perbaikan terutama dalam penggunaan rumusnya dimana realisasi yang sesuai target hanya mendapatkan nilai baik minimal (76). Untuk beberapa posisi jabatan di PNS, hal ini tentu tidak adil karena untuk jabatan tertentu misalnya di keuangan atau pembangunan inftrastruktur, untuk realisasi anggaran yang mendekati target 100\% merupakan pencapaian prestasi yang luar biasa, akan tetapi dalam SKP prestasi ini hanya diberikan nilai 76 (kategori baik). Kondisi seperti ini dirasakan tidak adil untuk sebagian PNS dan juga berbeda dengan prinsip penyelenggaraan anggaran berbasis kinerja dimana penyerapan anggaran yang sesuai target (100\%) seharusnya mendapatkan nilai yang sangat baik.

Selain itu yang penting digaris bawahi adalah hasil nilai capaian SKP antara fungsional umum dengan fungsional tertentu dimana belum adanya reward bagi fungsional umum seperti halnya dengan fungsional tertentu dalam hal kenaikan pangkat, jika nilai capaian SKP fungsional tertentu tinggi, tentunya ini akan berbanding lurus dengan pencapaian angka kredit yang dicapainya dengan reward kenaikan pangkat yang lebih cepat. Akan tetapi bagi fungsional umum maupun pejabat struktural sebagus atau setinggi apapun nilai SKP maka tetap tidak ada reward dalam hal kenaikan pangkat karena tetap akan reguler setiap 4 (empat) tahun sekali.

Sehubungan dengan permasalahan-permasalahan di atas maka diperlukan adanya kajian lebih lanjut mengenai objektivitas penilaian prestasi kerja PNS yang ideal dalam menjamin objektivitas pembinaan PNS.

\section{Penilaian Prestasi Pegawai}

\section{Penilaian Prestasi Kerja Aspek Kuantitas}

Penilaian capaian SKP aspek kuantitas dilakukan dengan membandingkan antara realisasi output $(\mathrm{RO})$ dengan target output (TO) dikalikan 100.

\section{Rumus aspek kuantitas :}

$$
\frac{\text { Realisasi Output }}{\text { Target Output }} \times 100
$$

Dalam aspek kuantitas, nilai capaian SKP tergantung dari realisasi yang dicapai oleh seorang pegawai. Target bersifat tetap dan tidak bisa dirubah sepanjang diluar faktor diluar kemampuan PNS.

Kendala yang ditemui dalam aspek kuantitas selama pengamatan penulis terkait hal teknis dan non teknis, tetapi tidak terkait dengan rumus yang ada. Hal ini benar adanya, di lapangan masih sering ditemui seperti kesalahan dalam menuliskan satuan kuantitas yang kurang pas dengan uraian tugas dan uraian tugas yang masih muncul walaupun target kuantitas o (nol). 


\section{Penilaian Prestasi Kerja Aspek Kualitas}

Kualitas merupakan aspek penting dalam setiap kegiatan atau kinerja pegawai. Sesuai Peraturan Kepala BKN No 1 Tahun 2013, pada target kualitas diberikan nilai paling tinggi 100 (seratus). Hal ini menunjukan bahwa kualitas sangat diutamakan demi mencapai hasil kerja yang maksimal.

Penilaian capaian SKP dari aspek kualitas dilakukan dengan membandingkan antara Realisasi Kualitas (RK) dengan Target Kualitas (TK) dikalikan 100.

$$
\begin{aligned}
& \text { Rumus aspek kualitas : } \\
= & \frac{\text { Realisasi Kualitas }}{\text { Target Kualitas }} \times 100
\end{aligned}
$$

Untuk mengukur realisasi output berkualitas atau tidak dengan menggunakan pedoman sebagai berikut :

\section{Pedoman Penilaian SKP Aspek Kualitas}

\begin{tabular}{|c|l|}
\hline Kriteria Nilai & \multicolumn{1}{|c|}{ Keterangan } \\
\hline $91-100$ & $\begin{array}{l}\text { Hasil kerja sempurna, dan pelayanan di atas tidak ada } \\
\text { kesalahan, tidak ada revisi, standar yang ditentukan dan lain- } \\
\text { lain. }\end{array}$ \\
\hline $76-90$ & $\begin{array}{l}\text { Hasil kerja mempunyai I (satu) atau 2 (dua) kesalahan kecil, } \\
\text { tidak ada kesalahan besar, revisi, dan pelayanan sesuai standar } \\
\text { yang telah ditentukan dan lain-lain. }\end{array}$ \\
\hline $61-75$ & $\begin{array}{l}\text { Hasil kerja mempunyai 3 (tiga) atau 4 (empat) kesalahan kecil, } \\
\text { dan tidak ada kesalahan besar, revisi, dan pelayanan cukup } \\
\text { memenuhi standar yang ditentukan dan lain-lain. }\end{array}$ \\
\hline $51-60$ & $\begin{array}{l}\text { Hasil kerja mempunyai 5 (lima) kesalahan kecil dan ada } \\
\text { kesalahan besar, revisi, dan pelayanan tidak cukup memenuhi } \\
\text { standaryang ditentukan dan lain-lain. }\end{array}$ \\
\hline 50 ke bawah & $\begin{array}{l}\text { Hasil kerja mempunyai lebih dari 5 (lima) kesalahan kecil dan } \\
\text { ada kesalahan besar, kurang memuaskan, revisi, pelayanan di } \\
\text { bawah standar yang ditentukan dan lain-lain. }\end{array}$ \\
\hline
\end{tabular}

Setiap pejabat penilai di akhir tahun menggunakan pedoman tersebut dalam memberikan penilaian dalam mengukur seberapa berkualitas output yang dihasilkan oleh PNS yang sedang dinilai.

Kendala dalam aspek kualitas relatif tidak ada, hanya terjadi di penentuan target di awal yang tidak menetapkan target kualitas sebesar 100. Maksud daripada kenapa target kualitas diharuskan sebesar 100 tidak boleh kurang maupun lebih adalah agar setiap PNS apapun jabatan dan jenjang jabatannya baik pelaksana, fungsional, maupun struktural dituntut untuk memberikan layanan maksimal karena setiap PNS harus memberikan pelayanan dengan mutu pekerjaan terbaik. 


\section{Penilaian Prestasi Kerja Aspek Waktu}

Waktu merupakan ukuran lama yang dibutuhkan untuk menyelesaikan suatu pekerjaan. Dalam menghitung nilai capaian SKP dari aspek waktu, terlebih dahulu menghitung persentase tingkat efisiensi waktu dari target waktu.

$$
\begin{gathered}
\text { Presentase efisensi waktu : } \\
100 \%-\frac{\text { Realisasi Waktu }}{\text { Target Waktu }} \times 100
\end{gathered}
$$

Jika nilai efisiensi waktu $\leq 24 \%$, maka menggunakan rumus :

$$
\begin{gathered}
\text { Rumus Aspek Waktu } \\
\frac{1,76 \times \text { Target Waktuu - Realisasi Waktu }}{\text { Target Waktu }} \times 100
\end{gathered}
$$

Jika nilai efisiensi waktu $\geq 24 \%$, maka menggunakan rumus :

$$
\begin{gathered}
\text { Rumus Aspek Waktu : } \\
76-\left[\left(\frac{1,76 \times \text { Target Waktu }- \text { Realisasi Waktu }}{\text { Target Waktu }} \times 100\right)-100\right]
\end{gathered}
$$

Berdasarkan rumus dalam aspek waktu dapat diartikan bahwa semakin lama realisasi waktu yang dipergunakan dari target waktu yang direncanakan, menunjukkan tingkat prestasi kerja yang semakin buruk atau sebaliknya semakin cepat realisasi waktu dari target waktu yang direncanakan (maksimal efisiensi waktu sampai dengan 24\%), menunjukkan tingkat prestasi kerja yang semakin baik atau sangat baik. Saat ini yang berkembang di kalangan PNS khususnya yang penulis cermati di wilayah kerja Kanreg III BKN bahwa untuk satuan waktu baik target maupun realisasinya diharuskan menggunakan satuan bulan.

Timbul pertanyaan bagaimana jika suatu pekerjaan bisa diselesaikan dalam jangka waktu minggu, hari, bahkan jam. Jika harus ditentukan menggunakan satuan bulan saja, maka ini bertentangan dengan prinsip objektif dalam penyusunan SKP bahwa dimulai dari penyusunan hingga penilaiannya, SKP harus sesuai dengan keadaan yang sebenarnya.

Hal ini menarik karena baik di dalam PP 46 tahun 2011 maupun Perka BKN Nomor 1 tahun 2013 tidak ada satu pasal pun yang mewajibkan satuan waktu harus menggunakan bulan. Jika diharuskan menggunakan satuan bulan maka sudah keluar dari prinsip objektif sehingga SKP dari seorang pegawai sudah tidak presisi lagi dengan kenyataannya.

Selain satuan waktu, yang menjadi sorotan penulis adalah karakteristik dari kegiatan tugas jabatan atau tupoksi dari pegawai yang berbeda waktu penyelesainnya, 
dimana hal ini dapat memberi peluang memperoleh nilai capaian SKP yang berbeda antara PNS yang realisasi waktunya dapat dipercepat dari target awal dengan PNS yang realisasi waktunya dikunci harus sesuai dengan target karena tidak mungkin dapat dipercepat dari target yang sudah ditentukan di awal tahun.

\section{Penilaian Prestasi Kerja Aspek Biaya}

Target biaya harus diperhitungkan dengan baik demi berjalannya setiap kegiatan. Biaya ini digunakan untuk setiap kegiatan tugas jabatan yang memerlukan biaya untuk merealisasikan tugasnya dalam periode berjalan. Artinya ada kegiatan tugas jabatan pegawai yang tidak memerlukan biaya. Sehingga dalam formulir sasaran kerja pegawai di aspek biaya tidak diisi dan nantinya dalam penilaiannya pun tidak masuk dalam perhitungan.

Dalam menghitung nilai capaian SKP dari aspek biaya, terlebih dahulu menghitung persentase tingkat efisiensi biaya dari target biaya.

$$
\begin{gathered}
\text { Presentase efisiensi biaya: } \\
100 \%-\frac{\text { Realisasi Biaya }}{\text { Taget Biaya }} \times 100
\end{gathered}
$$

Jika nilai efisiensi biaya $\leq 24 \%$ dari target yang ditentukan, maka untuk menghitung nilai capaian SKP dengan menggunakan rumus :

Rumus Aspek Biaya :

$$
\frac{1,76 \times \text { Target Biaya }- \text { Realisasi Biaya }}{\text { Target Biaya }} \times 100
$$

Jika nilai efisiensi biaya $\geq 24 \%$ dari target yang ditentukan, maka untuk menghitung nilai capaian SKP dengan menggunakan rumus :

$$
\begin{gathered}
\text { Rumus Apek Biaya : } \\
76-\left[\left(\frac{1,76 \times \text { Target Biaya }- \text { Realisasi Biaya }}{\text { Target Biaya }} \times 100\right)-100\right]
\end{gathered}
$$

Untuk PNS dengan jabatan fungsional maupun pelaksana tidak perlu mengisi aspek biaya di dalam SKP-nya, sehingga SKP-nya hanya terdiri atas 3 (tiga) aspek yaitu aspek kuantitas, aspek kualitas, dan aspek waktu. Aspek biaya muncul pada SKP PNS dengan jabatan struktural yang memiliki DIPA sendiri atau seorang Kuasa Pengguna Anggaran (KPA) atau Pejabat Pembuat Teknis Kegiatan (PPTK).

Hasil dari penghitungan di atas dapat diartikan bahwa semakin besar realisasi biaya yang diserap dari target biaya yang direncanakan, menunjukkan tingkat prestasi 
kerja yang semakin buruk atau sebaliknya semakin kecil realisasi biaya dari target biaya yang direncanakan (maksimal efisiensi biaya sampai dengan 24\%), menunjukkan tingkat prestasi kerja yang semakin baik atau sangat baik.

Penulis mencermati bahwa untuk aspek biaya dengan rumus yang berlaku saat ini perlu ada perbaikan karena dengan realisasi biaya yang sesuai target hanya mendapatkan nilai baik dengan nilai minimal.

Untuk beberapa posisi jabatan di PNS, hal ini tentu menjadi seakan tidak adil, seorang PNS dengan jabatan struktural yang juga menjabat selaku pejabat pembuat komitmen (PPK) di instansi pusat atau pejabat pelaksana teknis kegiatan (PPTK) di instansi daerah, untuk realisasi anggaran yang mendekati target saja sudah pencapaian prestasi yang luar biasa, akan tetapi di SKP untuk pencapaian target 100\% hanya diberikan nilai 76 yang merupakan nilai minimal untuk kategori baik.

$\mathrm{Hal}$ ini tentuya akan memberi rasa tidak nyaman bagi sebagian PNS jika nilai capaian SKP nantinya dijadikan dasar sebagai pemberian tunjangan kinerja karena tunjangan kinerja yang diperoleh akan lebih kecil dibandingkan dengan PNS lainnya.

\section{Penilaian Prestasi Kerja Aspek Perilaku Kerja}

Dalam penilaian perilaku kerja terdapat 6 aspek yang dinilai yakni orientasi pelayanan, integritas, komitmen, disiplin, kerja sama, dan kepemimpinan. Penilaian perilaku kerja pegawai yang meliputi 6 aspek tersebut dilakukan melalui pengamatan oleh pejabat penilai terhadap PNS sesuai kriteria yang ditentukan. Pejabat penilai dalam melakukan penilaian perilaku kerja PNS dapat mempertimbangkan masukan dari pejabat penilai lain yang setingkat di lingkungan unit kerja masing-masing.

Penting untuk dicermati bahwa syarat utama untuk kenaikan pangkat adalah penilaian prestasi kerja bernilai baik. Artinya nilai SKP dari masing-masing unsur perilaku kerja minimal bernilai baik. Sampai dengan saat ini masih banyak PNS di BTL-kan (berkas tidak lengkap) usul kenaikan pangkatnya karena masih ada saja nilai salah satu atau beberapa unsur perilaku kerjanya di bawah nilai baik. Ditegaaskan kembali bahwa nilai minimal baik (76) yang dimaksud sebagai syarat untuk kenaikan pangkat, bukan nilai rata-rata dari seluruh unsur perilaku kerja. Jika salah satu unsur ada yang bernilai kurang baik maka usul kenaikan pangkatnya akan ditolak. Sehingga setiap PNS dan bagian kepegawaian setiap instansi pemerintah perlu mencermati hal ini karena sampai saat ini masih sering ditemui nilai perilaku kerja sebesar 75 ke bawah akan tetapi masih tetap diusulkan kenaikan pangkatnya ke Kantor Regional III BKN.

\section{Objektivitas Penilaian Prestasi Kerja Terhadap Kenaikan Pangkat PNS}

Penilaian prestasi kerja PNS yang dilakukan oleh atasan langsung terhadap stafnya bertujuan untuk memperoleh bahan-bahan pertimbangan yang obyektif dalam pembinaan PNS. Salah satu bentuk pembinaan PNS yang utama adalah kenaikan 
pangkat, selain bentuk pembinaan lainnya seperti penempatan pegawai, mutasi, diklat, mengikuti sosialisasi/ workshop, izin belajar, tugas belajar, dan lain-lain. Syarat utama seorang PNS bisa naik pangkat adalah yang bersangkutan melampirkan penilaian prestasi kerjanya dalam 2 (dua) tahun terakhir, dulu kita mengenalnya dengan DP-3.

Kenaikan pangkat sebagai salah satu bentuk pembinaan kepada PNS mensyaratkan SKP sebagai syarat utamanya dan SKP dibuat dalam rangka objektivitas pembinaan PNS. Dalam perjalanannya ditemukan ke tidak objektivan dalam hal kenaikan pangkat bagi teman-teman strukual dan pelaksana dikarenakan nilai capaian SKP yang tidak berbanding lurus dengan kenaikan pangkat. Maksud daripada nilai capaian SKP yang tidak berbanding lurus adalah :

1) Berapapun nilai SKP yang diperoleh oleh seorang pelaksana maupun struktural maka hal ini tidak berpengaruh terhadap cepat atau lambatnya kenaikan pangkatnya, karena kenaikan pangkatnya tetap reguler setiap 4 (empat) tahun sekali.

2) Sedangkan untuk jabatan fungsional, nilai capaian SKP akan berbanding lurus dengan capaian angka kreditnya karena angka kredit didapat dari realisasi kuantitas atau output dikali nilai butir kegiatan.

Ketidakobjektifan bagi sebagian PNS disebabkan karena regulasinya mengatur seperti itu, bagi fungsional semakin tinggi capaian SKP maka angka kredit yang dikumpulkan juga semakin banyak. Para fungsional bisa naik pangkat dalam 2,5 tahun, 3 tahun, atau 3,5 tahun tergantung pencapaian angka kreditnya yang tercermin dari nilai capaian SKP nya. Sedangkan untuk PNS dengan jabatan pelaksana dan struktural kenaikan pangkatnya ditetapkan reguler setiap 4 tahun sekali.

\section{Penutup}

Penilaian prestasi kerja PNS berdasarkan sasaran kerja pegawai (SKP) dan perilaku kerja sudah objektif untuk aspek aspek kuantitas, aspek kualitas, dan aspek perilaku kerja karena penyelesaian masalah yang muncul dapat dilakukan perbaikan di akhir tahun saat dilakukan penilaian oleh pejabat penilai dan dapat dilakukan oleh seluruh jabatan PNS baik jabatan struktural, fungsional, maupun pelaksana. Namun untuk aspek waktu dan aspek biaya disimpulan belum objektif untuk PNS dengan jabatan pelaksana dan struktural dikarenakan ditemukan ketidakadilan dalam formula perhitungan yang diterapkan

Kendala penilaian prestasi kerja PNS aspek kuantitas, penentuan satuan kuantitas yang tidak sesuai dengan uraian tugas dan target kuantitas yang berubah yang diakibatkan oleh faktor-faktor diluar kemampuan dan faktor kelalalain. Aspek kualitas, penentuan target kualitas di awal tahun yang tidak bernilai 100 sebagai target kualitas dengan mutu terbaik yang harus diberikan. Aspek waktu, satuan waktu diharuskan menggunakan satuan bulan dan karakteristik dari uraian tugas dari PNS yang berbeda 
untuk masing-masing jabatan. Aspek biaya, realisasi yang mencapai target hanya mendapatkan nilai baik dengan skor paling minimal yaitu 76 (tujuh puluh enam). Dan terkahir aspek perilaku kerja , masih banyaknya PNS di BTL-kan proses usul kenaikan pangkatnya dikarenakan ada satu atau beberapa nilai unsur perilaku kerja yang nilainya kurang dari 76.

Solusi untuk mengatasi kendala pelaksanaan penilaian prestasi kerja PNS aspek kuantitas dengan melakukan penyesuaian target di akhir tahun dengan seizin atasan langsungnya sepanjang diakibatkan oleh faktor diluar kemampuan PNS seperti bencana alam, sakit, cuti melahirkan, dan pekerjaan yang input bahan kerjanya tergantung dari dari pihak/instansi lain. Aspek kualitas yaitu dengan melakukan perbaikan target kualitas menjadi 100 (kualitas mutu terbaik). Aspek waktu, dengan menggunakan satuan selain bulan, bisa minggu, hari, ataupun jam tergantung dari jangka waktu yang dibutuhkan untuk menyelesaikan suatu pekerjaan karena sepanjang satuan waktunya sama antara target dengan realisasinya maka tidak akan menjadi masalah. Dan dengan adanya perbaikan dari sisi regulasi atau kebijakan tersendiri untuk para PNS yang sifat atau karakteristik pekerjaannya tidak memberi peluang untuk dapat menperoleh capaian SKP yang lebih tinggi. Aspek biaya perlu adanya perbaikan dari sisi regulasi pada formula atau rumus aspek biaya agar penilaian dapat lebih objektif untuk semua jabatan PNS baik struktural, fungsional, maupun pelaksana. Aspek perilaku kerja yaitu bagian kepegawaian dari setiap instansi agar dapat lebih cermat jika ada salah satu atau beberapa unsur perilaku kerja yang nilainya di bawah 76 maka tidak perlu diusulkan proses kenaikan pangkatnya ke BKN.

\section{Daftar Pustaka}

Achmadi, Asmoro. 2009. Filsafat Pancasila dan Kewarganegaraan. Semarang: RaSail.

Budiarjo, Miriam. 2008. Dasar-Dasar Ilmu Politik. Jakarta: Gramedia Pustaka Utama.

Budiarto, Yohanes dan Rani Puspita Wardani, "Peran Keadilan Distributif, Keadilan Prosedural dan Keadilan Interaksional Perusahaan terhadap Komitmen Karyawan pada Perusahaan (Studi pada Perusahaan X)", Jurnal Psikologi Vol. 3 No. 2, Desember 2005

Dharma, Agus. 1985. Manajemen Prestasi Kerja. Edisi Pertama. Jakarta: Rajawali.

Djatmika, Sastra dan Marsono. 1995. Hukum Kepegawaian di Indonesia. Jakarta: Djambatan.

Gomes, Faustino Cardoso. 2000. Manajemen Sumber Daya Manusia. Jakarta: Andi Offset. H.R. Ridwan. 2007. Hukum Administrasi Negara, Jakarta: Raja Grafindo Persada.

Handoko, Hani. 1994. Manajemen Personalia dan Sumber Daya Manusia. Yogyakarta: BPFE.

Hardianto. 2005. Sistem Pembinaan Pegawai Negeri Sipil di Indonesia (Makalah). Jakarta: BKN.

Hariandja, Marihot. 2002. Manajemen Sumber Daya Manusia. Jakarta: Grasindo. 
Hartini, Sri, dkk. 2008. Hukum Kepegawaian di Indonesia. Jakarta: Sinar Grafika.

Hartini, Sri. 2010. Hukum Kepegawaian di Indonesia. Jakarta: Sinar Grafika.

Hasibuan, Malayu. 2000. Manajemen Sumber Daya Manusia. Jakarta: Bumi Aksara.

Herman. 2004. Pengaruh Pembinaan terhadap Perilaku Pegawai Negeri Sipil. Jakarta: Puslitbang BKN.

Khaddury, Majid. 1999. Teologi Keadilan Perspektif Islam. Surabaya: Risalah Gusti.

Magnis Suseno, Franz. 1994. Etika Politik Prinsip-prinsip Moral Dasar Kenegaraan Modern. Jakarta: Gramedia Utama.

Marbun, S.F.. 2013. Hukum Administrasi Negara II. Yogyakarta: FH UII Press.

Mathis, R.L, dan Jackson J.H. 2006. Manajemen Sumber Daya Manusia. Jakarta: Salemba Empat, Edisi Kesepuluh.

Meyrs, D.G. 2013. Social Psycology (13Th.ed). New York: Mc Graw-Hill.

Musanef. 2005. Manajemen Kepegawaian Di Indonesia. Jakarta: Gunung Agung.

Nasution, Harun. 1995. Islam Rasional Gagasan dan Pemikiran. Bandung : Mizan.

Nawawi, H. Hadari. 1997. Manajemen Sumber Daya Manusia. Yogyakarta: Gajah Mada University Press.

Poggi, Gianfranco. 1992. The Development of the Modern State "Sosiological Introduction", California: Standford University Press.

Prabu Mangkunegara, Anwar. 2000. Manajemen Sumber Daya Manusia Perusahaan. Bandung: Remaja Rosda Karya.

Rato, Dominikus. 2010. Filsafat Hukum: Mencari, Menemukan, dan Memahami Hukum. Surabaya: Laksbang Justitia.

Rawls, Jhon. 2006. A Theory of Justice, Jogjakarta: Pustaka Pelajar.

Rivai, Veithzal. 2005. Performance Appprasial. Jakarta: Raja Grafindo Persada.

Rusli, Budiman. 2013. Kebijakan Publik. Membangun Pelayanan Publik yang Responsif. Bandung: Hakim Publisher.

Sembiring, Masana. 2012. Budaya Dan Kinerja Organisasi. Bandung: Fokusmedia.

ST. Marbun, dan Moh Mahfud MD. 2011. Pokok-pokok Hukum Administrasi Negara. Yogyakarta: Liberty.

Stewart, C.J \& Cash, Jr, W.B. 2000. Interviewing: Principles and Practices. New York: McGraw-Hill.

Sugiyono. 2014. Metode Penelitian Kuantitatif, Kualitatif, dan Kombinasi (Mixed Methods). Bandung: Alfabeta.

Thamrin, Husni. 2013. Hukum Pelayanan Publik di Indonesia. Yogyakarta: Aswaja Pressindo Cet. II.

Thoha, Miftah. 1999. Manajemen Kepegawaian Sipil di Indonesia. Jakarta: Kencana Press.

Triatmodjo, Soedibyo. 1983. Hukum Kepegawaian (Mengenai Kedudukan Hak dan Kewajiban Pegawai Negeri Sipil). Jakarta: Ghalia Indonesia.

W. Sudibyo. 2011. Reformasi Birokrasi, Jakarta: Bumi Aksara.

Waluyo, Bambang. 2002. Penelitian Hukum Dalam Praktek. Jakarta: Sinar Grafika.

Widjaja, A.W. 2007. Administrasi Kepegawaian. Jakarta: Rajawali Pres.

Yamin. 1959. Naskah Persiapan UUD 1945: Risalah Sidang BPUPKI/PPKI, Jakarta : Sekretariat Negara RI. 